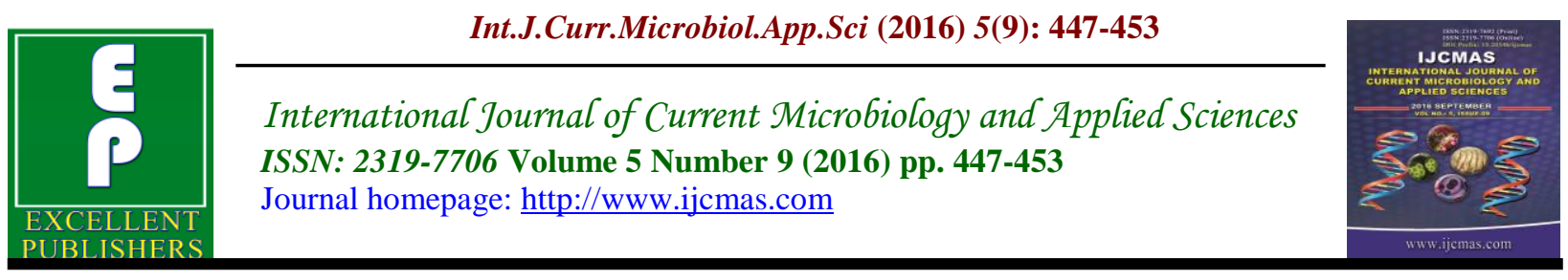

Review Article

http://dx.doi.org/10.20546/ijcmas.2016.509.048

\title{
Applications of Immunostimulants in Aquaculture: A Review
}

\author{
B. Deivasigamani* and Vasuki Subramanian \\ CAS in Marine biology, Faculty of Marine Sciences, Annamalai University, \\ Parangipettai-608502 Tamilnadu, India \\ *Corresponding author
}

\begin{tabular}{|c|c|}
\hline & A B S T R A C T \\
\hline $\begin{array}{l}\text { Ke y w o r d s } \\
\text { Immunostimulants, } \\
\text { Aquaculture, } \\
\text { Vibrio sp. } \\
\text { Seaweeds, } \\
\text { poor water quality. }\end{array}$ & \multirow{3}{*}{$\begin{array}{l}\text { Aquaculture fish production has increased significantly over the past few } \\
\text { decades, which has led to intensive fish culture practices where stressors } \\
\text { like overcrowding, transport, handling, grading and poor water quality are } \\
\text { common. It is widely demonstrated that farmed fish are more susceptible to } \\
\text { disease agents due to the stressors posed by intensive rearing. Bacterial } \\
\text { infection causes a high rate of mortality in human population and } \\
\text { aquaculture organisms. It is a primary pathogen of fishes, which causes a } \\
\text { systemic infection leading to disease and death. The development of } \\
\text { aquaculture has seen considerable economic losses due to pathogens of } \\
\text { Vibrio sp. The uses of immunostimulants of seaweeds in aquaculture are } \\
\text { presented in this review. }\end{array}$} \\
\hline Article Info & \\
\hline $\begin{array}{l}\text { Accepted: } \\
\text { 15 August } 2016 \\
\text { Available Online: } \\
\text { 10 September } 2016\end{array}$ & \\
\hline
\end{tabular}

\section{Introduction}

\section{Bacterial pathogens}

Bacterial diseases are of great concern in aquaculture, mainly because they are cause of severe loss of production with high economic impact. Several species of Vibrio and Aeromonas are common bacteria in marine environments, have been reported as pathogenic for shellfish andfish. Vibrio harveyi has been reported as pathogenic for penaeid shrimps, and associated to mortality of abalone (Haliotis tuberculata). Vibrio sp have been associated mortality of bivalve molluscs (oysters, clams and scallops) in summer. Listonella (Vibrio) anguillarum, Vibrio alginolyticus, and $V$. harveyi are responsible for larval vibriosis in different mollusc species (Garnier et al., 2007; Paillard et al., 2004). Aeromonas salmonicida subsp. salmonicida is the causative agent of furunculosis, a bacterial septicaemia of salmonid fish. Other species of Aeromonas are opportunistic pathogens or are found in commensal or symbiotic relationships with animal hosts. Photobacterium damselae subsp. piscicida has been recognized as the causative agent of fish photobacteriosis (Romalde, 2002). Emergence of multi-drug resistant pathogens now presents an increasing global challenge to veterinary medicine. Therefore, there is a continuous need to develop novel antimicrobial agents to minimize the threat 
of further antimicrobial resistance (Celiktas et al., 2007).

Antibiotics have revolutionised mankind's health status, allowing treatment of life threatening infections. However with the increasing occurrence of bacterial resistance against available antibiotics, it has now become essential to look for newer antibiotics. Most of the antibiotics available today come from natural origin, especially from various microbial or marine sources (Sarker et al., 2007). Antibiotic treatment of bacterial diseases in fish culture has been applied for many years. The occurrence of antibiotic resistant bacteria associated with fish diseases is a worldwide problem in aquaculture, which has received considerable attention in the last years and continues to increase due to the absence of a more effective and safer use of antibiotics. The prevention and treatment of these infectious diseases by applying products from marine organisms appears as a possible alternative. Hence, the interest in marine organisms as a potential and promising source of pharmaceutical agents has increased during the last years (Mayer et al., 1999).

\section{Seaweeds}

Seaweeds are suitable for animal feed applications. Seaweeds were containe carbohydrates, protein and minerals as well as bioactive compounds such as polyphenols, terpenoids, carotenoids and tocopherols. Seaweeds have been reported to produce a great variety of metabolic compounds which are not produced by terrestrial plants (Plaza et al., 2008; Abbas et al., 2003).

Seaweeds are considered as a source of bioactive compounds as they are able to produce a great variety of secondary metabolites characterized by a broad spectrum of biological activities. Compounds with cytostatic, antiviral, anthelmintic, antifungal, and antibacterial activities have been detected in green, brown and red algae (Bibiana et al., 2012). Pharmaceutical importance of seaweed is well known all over the world and extensive efforts were given to bring out substances from algae. There are number of reports regarding the medicinal importance of sea weeds belonging to Phaeophyceae, Rhodophyceae and Chlorophyceae from all over the world (Kolanjinathan et al., 2009). Many studies were reported earlier on the antimicrobial study of marine algae (Battu et al., 2011). Seaweeds with elevated protein content and production rates are receiving increasing attention as novel feeds with potential nutritional benefits and as possible ingredient in fish diets. Interest in the use of edible seaweeds in the development of lowcost, highly nutritive diets for human and animal nutrition, especially animal nutrition since sea vegetables are able to accelerate the growth of such species as big oysters, tilapia, salmon, trout, etc., all of great commercial interest (Fleming et al., 1996). Rapid expansion of fish culture in recent years is demanding the development of nutritious fish feeds, as well as better feed utilization, due to the fact that feed cost may increase the cost of fish production by 50$80 \%$.

Seaweeds contain several immunologically active substances. In fish some substances obtained from seaweeds, mainly polysaccharides, can modify the activity of some components of the immune system and increase protection against certain diseases. Carrageenan, a polysaccharide abundant in certain red seaweeds, induced an increase in macrophage phagocytic activity and in the resistance against bacterial infections after being injected intraperitoneally in carp 
(Cyprinus carpio) and sodium alginate was found to enhance migration of carp head kidney phagocytes to the peritoneal cavity, to increase phagocytic activity (Gopalakkanan et al., 2006) and the survival of juvenile turbot challenged with Vibrio anguillarum (Fujiki et al., 1997).

\section{Bioactive compounds}

Number of bioactive compounds which have been isolated and identified from seaweeds include sulphated polysaccharides (laminarins and fucoidans), polyphenols such as phlorotannins, carotenoid pigments such as fucoxanthin (Zhou et al., 2012) and astaxanthin, sterols and mycosporine-like amino acids (MAAs) to name some. Presence of polyphenols such as catechin, epicatechin, epigallocatechin gallate and gallic acid are reported in the green seaweed Halimada. Reported the presence of 14 polyphenols, namely gallic acid, catechin, epicatechin, rutin, pcoumaric acid, myricetin, quercetin and protocatechuic, vanillic, caffeic, ferulic, chlorogenic, syringic and gentisic acids in the solvent extracts of Stypocaulon scoparium (Lopez et al., 2011) Reported the extraction of bioactive phenolic acids (protocatechuic, phydroxybenzoic, 2, 3-dihydroxybenzoic, chlorogenic, caffeic, p-coumaric, salicylic acid), cinnamic acid and hydroxybenzaldehydes (phydroxybenzaldehyde, $\quad 3,4$ dihydroxybenzaldehyde) from food products of Porphyra tenera and Undaria pinnatifida. Fucoxanthin and phlorotannins have been identified as active antioxidant compounds from Hijika fusiformis and Sargassum kjellamanianum, respectively. Aerial parts of green seaweeds have been reported to yield diterpenes, sesquiterpenes and related compounds having antibacterial and antifungal feed is fish meal which has high protein quality and palatability. Substituting high price fish meal in aqua feed with less expensive protein source in one way of reducing protein production cost. For the reason this study have been conducted to trash fish, shrimp waste and acetes was used for the alternative protein feed for fish. It reduced the production cost of the fish. Shrimp head waste, which represents about $33 \%$ of the shrimp weight, is almost completely discarded. The under utilization of the shrimp head waste posing a serious disposal problem, contributes to the overall cost of the production. One of the possible solutions of this problem is to transform processing waste into either silage or flour and use this material in the formulation of animal or fish feeds (Xu et al., 2003).

Fish have high dietary protein requirement. In aquaculture reducing the feeding costs could be key factor for successful development. Level of dietary protein is of fundamental importance, because it significantly influences growth, survival, and yield of fish as well as economics of a farming industry by determining the feed cost which is typically the largest operational cost. Increase in dietary protein has often been associated with higher growth rate in many species. However, there is a certain level beyond which further growth is not supported, and may even decrease (Deng et al., 2006). Considerable research effort has been expended to determine the quantity and quality of dietary protein necessary to achieve optimum performance of fish.

The immune system is classified into innate (non-specific) and adaptive (specific) immune systems. The innate immune system of vertebrate is the first line of defense against invading pathogens (Kvale et al., 2007). The innate system's response to infectious pathogens is determined by the evolutionary lineage and genetic makeup; it 
has been tailored through time by environmental factors and pathogenic associations they maintain stable conditions (homeostasis) during development and growth and following inflammatory reaction or tissue damage (Alvarez-Pellitero, 2008). The major components of the innate immune system are macrophages, monocytes, granulocytes, and humoral elements, including lysozyme or complement system. In fish and shellfish the innate immune system consists of neutrophil activation, production of peroxidase and oxidative radicals, together with initiation of other inflammatory factors (Magnadottir, 2010). One of the most promising methods of controlling diseases in aquaculture is by strengthening the defense mechanism of fish through prophylactic administration of immunostimulants, which is considered as a promising alternative to chemotherapy and vaccines because of their broad spectrum activity, cost effectiveness, and eco-friendly disease preventative measure. A number of immunostimulants have been developed and found to be effective in fish and shellfish including chemical agents, bacterial components, polysaccharides, and animal or plant extracts. The immunostimulants are effective means of increasing the immunocompetency and disease resistance by enhancing both specific and non-specific defence mechanisms of fish and shellfish and other animals. Immunostimulants, also called immunomodulators, adjuvants, or biological response modifiers, stimulate the immune system.

Glucans with a strong immunomodulating activity have been well studied in fishes. Some investigators used in vitro culture of macrophages with glucan but most carried out in vivo studies. Fish in intensive conditions are more susceptible to microbial infection, especially in larval stages. During stress, immunostimulants can provide resistance to pathogens. Few immunostimulants can be used in aquaculture. There are two types of glucans: $\alpha-$ and $\beta$-, the numbers of which clarify the type of O-glycosidic bond. Glucans are commercially significant as immunostimulating agents. Different types of $\beta$-glucans have been used to increase resistance of fish and crustaceans against bacterial and viral infections. The health, growth, and general performance of farmed shrimp and fish may be improved by the use of $\beta$-glucans. Product source, animal species, development stage of the target organism, dose and type of glucan, route, time schedule of administration, and association with other immunostimulants affect the immunomodulatory effects of glucans. The immunostimulatory effects of glucan, chitin, lactoferrin, levamisole, vitamins $\mathrm{B}$ and $\mathrm{C}$, growth hormones, and prolactin have been reported in fish and shrimp. These immunostimulants mainly facilitate the function of phagocytic cells and increase their bactericidal activities. Several immunostimulants also stimulate natural killer cells or complement lysozyme and antibody responses of fish. The most effective method of administration of immunostimulants to fish is by injection. The efficacy of oral and immersion methods decreases with long-term administration. In some cases, overdoses of immunostimulants induce immunosuppression in fish. Growth promoting activity has been noted in fish or shrimp treated with glucan or lactoferrin. Immunostimulants can overcome immune suppression by sex hormones. For the effective use of immunostimulants, the timing, dosage, method of administration, and physiological condition of the fish need to be taken into consideration. Immunostimulants can reduce the losses caused by disease in aquaculture, however, they may not be effective against all diseases (Subha Ganguly et al., 2010). 


\section{Acknowledgements}

The authors are grateful to the Science and Engineering Research Board (SERBF. No.SR/FT/LS-142/20 Department of Science and Technology (DST), Government of India, New Delhi for their financial support. The author sincerely thank for Prof. Dr. K. Kathiresan, Dean, Faculty of Marine Sciences, CAS in Marine Biology, Annamalai University, Parangipettai608502, TamilNadu, India.

\section{References}

Abbas, G. and Siddiqui, P.J.A. 2003. Effect of feeding rate on growth, feed conversion and body composition of juvenile mangrove red snapper reared in seawater tanks. Paki. J. Zoolo., 35: $151-156$.

Ainsworth, A.J. 1994. $\beta$-glucan inhibitable zymosan receptor on channel catfish neutrophils. Vet. Immunolo. Immunopathol., 41: 141-152.

Airanthi, M.K.W.A., Hosokawa, M. and Miyashita, K. 2011. Comparative antioxidant activity of edible Japanese brown seaweeds. J. Food Sci., 76: C104-C111.

Alvarez-Pellitero, P. 2008. Fish immunity and parasite infections: from innate immunity to immunoprophylactic prospects. Vet. Immunol. Immunopathol., 126: 171-198.

Battu, G.R., Ethadi, S., Prayaga Murthy, P., Praneeth, V.S. and Rao, M. 2011. Invitro anti bacterial activity and preliminary phytochemical screening of three algae from Vishakhapatnam Coast, Andhra Pradesh, India. Int. J. Pharm. Pharm. Sci., 3(4): 399-401.

Bibiana, M.A., Nithya, K., Manikandan, M.S., Selvamani, P. and Latha, S. 2012. Antimicrobial evaluation of the organic extracts of Sargassum wightii
(Brown Algae) and Kappaphycus alwarezii (Red Algae) collected from the Coast Of Meemesal, Tamilnadu. IJPCBS, 2(4): 439-446

Buschmann, A.H., Correa, J.A., Westermeier, R., HernandezGonzalez, M. and Norambuena, R. 2001. Red algal farming in Chile: a review. Aquaculture, 194: 203-220.

Cavalheiro, J.M.O., de Souza, E.O. and Bora, P.S. 2007. Utilization of shrimp industry waste in the formulation of tilapia (Oreochromis niloticus L) feed. Biores. Technol., 98:602-606

Celiktas, O.Y., Kocabas, E.E.H., Bedir, E., Sukan, F.V., Ozek, T. and Baser, K.H.C. 2007. Antimicrobial activities of methanol extracts and essential oils of Rosmarinus officinalis, depending on location and seasonal variations. Food Chem., 100: 553-559.

Deng, J., Mai, K., Ai, Q., Zhang, W., Wang, X., Xu, W. and Liufu, Z. 2006. Effects of replacing fish meal with soy protein concentrate on feed intake and growth of juvenile Japanese flounder, Paralichthys olivaceus. Aquaculture, 258: 503-513.

El-Sayed, A.F.M., Mansour, C.R. and Ezzat, A.A. 2003. Effect of dietary protein level on spawning performance of Nile tilapia brood stock reared at different water salinities Oreochromis niloticus. Aquaculture, 220: 619-632.

Fleming, A.E., Van Berneveld, R.J. and Hone, P.W. 1996. The development of artificial diets for abalone: a review and future dictions Aquaculture. A review and future directions. Aquaculture, 140: 5-53.

Fujiki, K. and Yano, T. 1997. Effects of sodium alginate on the non-specific defence system of the common carp (Cyprinus carpio L.). Fish. Shellfish Immunol., 7:417-27.

Garnier, M., Labreuche, Y., Garcia, C., 
Robert, M. and Nicolas, J.L. 2007. Evidence for the involvement of pathogenic bacteria in summer mortalities of the Pacific oyster Crassostrea gigas. Microbial. Ecol., 53: 187-196.

Gopalakkanan, A. and Arul, V. 2006. Immunomodulatory effects of dietary intake of chitin, chitosan and levamisole on the immune system of Cyprinus carpio and control of Aeromonas hydrophila infection in ponds. Aquaculture, 225: 179-187.

Hwang, P.A., Wu, C.H., Gau, S.Y., Chien, S.Y. and Hwang, D.F. 2010. Antioxidant and Immune stimulating activities of Hot-water extract from Seaweed Sargassum Hemiphyllum. J. Marine Sci. Tech., 18(1): 41-46

Kolanjinathan, K. and Stella, D. 2009. Antibacterial activity of marine macro algae against human pathogens. Recent Res. Sci. Technol., 1(1): 20-22.

Kvale, A., Nordgreen, A., Tonheim, S.K. and Hamre, K. 2007. Problem of meeting dietary protein requirements in intensive aquaculture of marine fish larvae, with emphasis on Atlantic halibut (Hippoglossus hippoglossus L.). Aquac. Nutr., 13: 170.

Lopez, A., Rico, M., Rivero, A. and de Tangil, M.S. 2011. The effects of solvents on the phenolic contents and antioxidant activity of Stypocaulon scoparium algae extracts. Food Chem., 125: 1104-1109.

Magnadottir, B. 2006. Innate immunity of fish- Overview. Fish Shellfish Immunol., 20: 137-51.

Magnadottir, B. 2010. Immunological control of fish diseases. Mar. Biotechnol., 12: 361- 379.

Mayer, A.M.S. and Hamann, M.T. 2002. Marine pharmacology in 1999: compounds with antibacterial, anticoagulant, antifungal, anthelmintic, anti-inflammatory, antiplatelet, antiprotozoal and antiviral activities affecting the cardiovascular, endocrine, immune and nervous systems, and other miscellaneous mechanism of action. Comp. Biochem. Physiol., 132: 315-339.

Narnaware, Y.K., Baker, B.I. and Tomlinson, M. 1994. The effect of various stresses corticosteroids and adrenergic agents on phagocytosis in the rainbow trout. Fish Physiol Biochem., 13: 131-140.

Onofrejova, L., Vasickova, J., Klejdus, B., Stratil, P., Misurcova, L,. Kracmar, S., Kopecky, J. and Vacek, J. 2010. Bioactive phenols in algae: The application of pressurized-liquid and solid-phase extraction techniques. $J$. Pharma. Biomedi. Anal., 51: 464-470.

Paillard, C., Le Roux, F. and Borrego, J.J. 2004. Bacterial disease in marine bivalves, a review of recent studies: trends and evolution. Aquatic Living Resources., 17: 477-498.

Plaza, M., Cifuentes, A. and Ibanez, E. 2008. In the search of new functional food ingredients from algae. Trends in Food Sci. Technol., 19: 31-39.

Puglisi, M.P., Tan, L.T., Jensen, P.T. and Fenical, W. 2004. Capisterones A and $\mathrm{B}$ from the tropical green alga Penicillus capitatus: Unexpected antifungal defences targeting the marine pathogen Lindra thallasiae. Tetrahedron., 60: 7035-7039.

Rajasekar Thirunavukkarasu, Priyadharshini Pandiyan, Kumaran Subaramaniyan, Deivasigamani Balaraman, Sakthivel Manikkam, BalamuruganS adaiyappan and George Edward Gnana Jothi.2014. Screening of marine seaweeds for bioactive compound against fish pathogenic bacteria and active fraction analysed by gas chromatography - mass 
spectrometry. J. Coastal Life Med., doi:10.12980/JCLM.2.2014J48. 2(5): 367-375

Romalde, J.L. 2002. Photobacterium damselae subsp. piscicida: an integrated view of a bacterial fish pathogen. Int. Microbiol., The Official J. Spanish Soc. Microbiol., 5: pp. 3-9.

Sarker, S.D., Nahar, L. and Kumarasamy, Y. 2007. Microtitre plate-based antibacterial assay incorporating resazurin as an indicator of cell growth, and its application in the in vitro antibacterial screening of phytochemicals. Methods, 42: 321324.

Secombes, C.J. 1996. The nonspecific immune system: cellular defenses. In: Iwama, G., Nakanishi, T. (Eds.). The Fish Immune System. Academic Press, New York. pp. 63-103.

Skjermo, J., Defoort, T., Dehasque, M., Espevik, T., Olsen, Y., Skjak-brfek, G., Sorgeloos, P. and Vadstein, O. 1995. Immunostimulation of juvenile turbot (Scophthalmus maximus L.) using an alginate with high mannuronic acid content administered via the live food organism Artemia. Fish. Shellfish Immunol., 5: 531-544.

Subha Ganguly, Indira Paul, Sunit Kumar Mukhopadhayay. 2010. Application and Effectiveness of Immunostimulants, Probiotics, and Prebiotics in Aquaculture: A Review.
The Israeli J. Aquaculture Bamidgeh, 62(3): 130-138.

Xu, N., Fan, X.A., Yan, X., Li, X., Niu, R. and Tseng, C.K. 2003. Antibacterial bromophenols from the marine red alga Rhodomela confervoides. Phytochem., 62: 1221- 1224.

Yan, X.J., Li, X.C., Zhou, C.X. and Fan, X. 1996. Prevention of fish oil rancidity by phlorotannins from Sargassum kjellmanianum. J. Applied Phycol., 8: 201-203.

Yoshie, Y., Wand, W., Hsieh, Y.P. and Suzuki, T. 2002. Compositional difference of phenolic compounds between two seaweeds, Halimeda sp. J. Tokyo University of Fisheries., 88: 21-24.

Zhou, J., Huang, J. and Song, X.L. 2003. Applications of immunostimulants in aquaculture. Mar. Fish. Res., 24: 7079.

Zhou, Q., Wang, L., Wang, H., Xie, F. and Wang, T. 2012. Effect of dietary vitamin-C on the growth performance and innate immunity of juvenile cobia (Rachycentron canadum). Fish Shellfish Immunol., 32: 969-975.

Zou, Y., Qian, Z.J., Li, Y., Kim, M.M., Lee, S.H. and Kim, S.K. 2008. Antioxidant effects of phlorotannins isolated from Ishige okamurae in free radical mediated oxidative systems. J. Agri. Food Chem., 56: 7001-7009.

\section{How to cite this article:}

Deivasigamani, B., and Vasuki Subramanian. 2016. Applications of Immunostimulants in Aquaculture: A Review. Int.J.Curr.Microbiol.App.Sci. 5(9): 447-453. doi: http://dx.doi.org/10.20546/ijcmas.2016.509.048 